\title{
Factors that Influence the Perceived Healthiness of Food-Review
}

\author{
Brigitta Plasek*, Zoltán Lakner and Ágoston Temesi
}

Department of Food Chain Management, Institute of Agrobusiness, Szent István University, Villányi Str. 29-43, 1118 Budapest, Hungary; lakner.zoltan@etk.szie.hu (Z.L.); temesi.agoston@etk.szie.hu (Á.T.)

* Correspondence: plasek.brigitta@etk.szie.hu; Tel.: +36-1-305-7100 (ext. 6178)

Received: 22 May 2020; Accepted: 22 June 2020; Published: 24 June 2020

\begin{abstract}
The interest of consumers is the consumption of healthy food, whereas the interest of food manufacturers is that consumers recognize the produced "healthier" food items on the shelves, so they can satisfy their demands. This way, identifying the factors that influence the perceived healthiness of food products is a mutual interest. What causes consumers to consider one product more beneficial to health than another? In recent years, numerous studies have been published on the topic of the influence of several health-related factors on consumer perception. This analysis collected and categorized the research results related to this question. This review collects 59 articles with the help of the search engines Science Direct, Wiley Online Library, MDPI and Emerald Insight between 1 January 2014 and 31 March 2019. Our paper yielded six separate categories that influence consumers in their perception of the healthiness of food items: the communicated information-like FoP labels and health claims, the product category, the shape and colour of the product packaging, the ingredients of the product, the organic origin of the product, and the taste and other sensory features of the product.
\end{abstract}

Keywords: perceived healthiness; product attributes; healthy food; consumer perception; food packaging; consumer behavior

\section{Introduction}

Which food can be considered beneficial to health? Science and consumers answer this question differently. According to certain sources, there is no precise definition of what can be considered healthy food, or else existing definitions are not yet appropriate [1-3]. The understanding of the category of "healthy food" differs even among experts; moreover, some treat the words "healthy" and "nutritious" as synonyms [4,5]. What can be considered healthy for whom depends on gender, age, metabolism, obesity, diseases or sensitivities. A nutritious food product generally considered definitely beneficial to health with several positive effects in case of certain diseases can be harmful for consumers suffering from other diseases [6].

Let us illustrate the effort to define healthy food with two examples. In their article, Zaheer and Bach [7] (p. 1) applied the following definition: "Per the United States Food E Drug Administration (FDA), Healthy foods are defined as those that are "low in fat, low in saturated fat, contain at least $10 \%$ of daily value for vitamins $A, C$, calcium, iron, protein fiber" and are limited in amount of sodium and cholesterol (USFDA)." Rodman and his colleagues [5] (p. 83) employed the following definition for their research: "Foods that provide essential nutrients and energy to sustain growth, health and life while satiating hunger; usually fresh or minimally processed foods, naturally dense in nutrients, that when eaten in moderation and in combination with other foods, sustain growth, repair and maintain vital processes, promote longevity, reduce disease, and strengthen and maintain the body and its functions. Healthy foods do not contain ingredients that contribute 
to disease or impede recovery when consumed at normal levels. (University of Washington Center for Public Health Nutrition (UWCPHN) 2013 [8])".

Dieticians argue that there is no such thing as healthy or unhealthy food; instead, there is only appropriate or inappropriate diet (e.g., [1]). However, since consumers consider certain foods healthy, while others unhealthy, it is important for us to know how they make this distinction. Mai and Hoffman [9] (p. 8) use the term perceived healthiness, which, based on Howlett et al. [10], they define as "Perceived healthiness is a consumer's expectation of a product's influence on his or her state of health". The importance of "perceived healthiness" is also supported by the research findings on health claims by Steinhauser and colleagues [11] that the higher the level of perceived healthiness of a product is, the more likely it is that the product will be purchased. All this becomes a factor that also increases the willingness to pay and purchase if it takes into account what influences the credibility of the health benefits of a product [12].

The effects of food on health is a widely researched topic, which gets attention from various aspects, thus our knowledge-base related to its consumer perception is also expanding. In their review, Niebylski and colleagues [13] examined the effects of taxation, subsidies and easy access on the consumption of products considered healthy. According to the results of Provencher and Jacob's review [14] specifically on perceived healthiness, cognitive factors-among them, brand and type of product-have an effect on the perceived healthiness of food, but such features do not influence the choice and intake of food. The reviews of Alba and Williams [15], and Krishna [16] highlight the topic that continues to be researched ever since, namely that the perceived healthiness of food has an effect also on the assessment of the taste of food (e.g., $[17,18])$. However, research attests that the perception of the healthiness of food is not influenced by one factor only, but by a combination of factors $[19,20]$, so we can state that this topic is highly complex and important both for consumers and companies.

The aim of our literature review is to assemble earlier research and survey the factors that influence consumers in their perception of the healthiness of food.

\section{Research Methodology}

In an attempt to access the articles related to the perceived healthiness of food, we employed several search engines-Science Direct, MDPI, Emerald Insight, Wiley Online Library—in our literature analysis. In recent years, numerous review-type articles touching on the topic of healthiness have been published (e.g., [12-18,21,22]), but they only fleetingly mention the issue. The present literature review, however, specifically approaches the topic from the consumers' point of view and so examines the factors which, according to research literature, influence consumer perception of the healthiness of food.

Between 2012 and 2016, several review articles touched on the topic of perceived healthiness of food $[13,15,16,21,22]$ or chose it as their main topic [14]. However, it has remained a widely researched area ever since, so we focused on the time period that followed. Articles published between 1 January 2014 and 31 March 2019 were selected using the following terms:

I. "perceived healthiness of food"

II. "evaluating food product healthfulness" OR "evaluation of food healthiness"

We looked for the terms in the title, the abstract or among the key words; naturally, because of the way they work, there were slight differences when using the different search engines.

In the I. case, on the ScienceDirect surface we looked for the exact term "perceived healthiness" in quotation marks in the "title, abstract or keywords" fields, while "food" appeared in the "terms" field. On the MDPI page, a very similar method was used, "perceived healthiness"—again in quotation marks-was searched for in the abstract, while "food" was searched for in "all fields". Between the two terms specified in quotation marks, we used the AND relationship to make sure that the search results include both terms. On the Emerald Insight surface, we looked for the complete terms in the abstract and the title, while with Wiley Online Library, in the abstract only, without quotation marks. 
In the II. case, on the ScienceDirect search field first "evaluating healthiness", then "evaluation of healthiness" in quotation marks was in the "title, abstract or keywords" field, while "food" was in the terms field. Very similarly to this and point I, on MDPI, the previously mentioned terms were searched for in the abstract, while the term "foods" was searched for in all fields. Just like in the first case, we ran the search with the AND relationship between the search terms. With Wiley and Emerald Insight, we collected the articles in a similar way, looking for the terms in the abstract only and in the title and the abstract, respectively. The search results and the filtering of hits are illustrated in Figure 1.

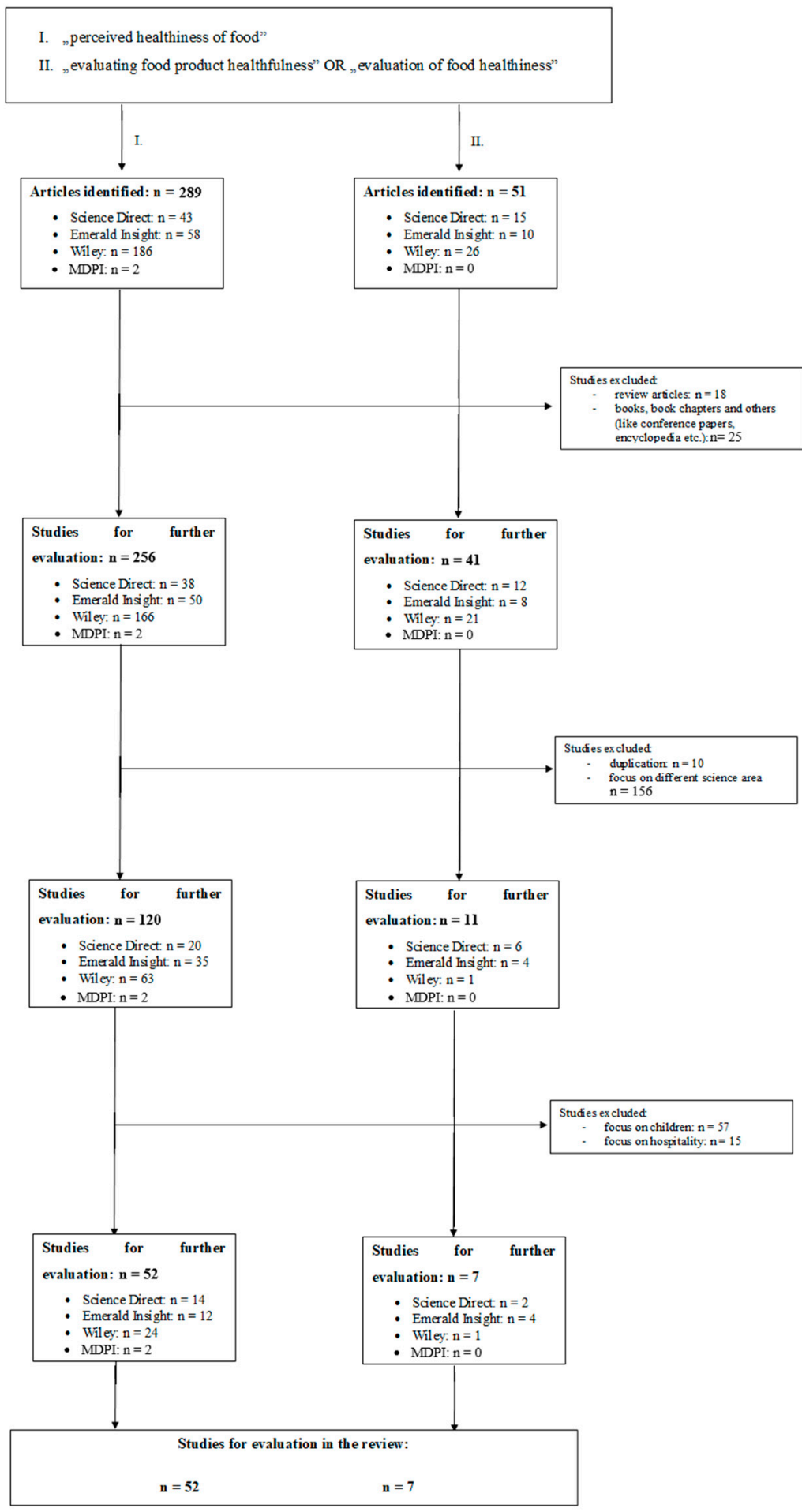

Figure 1. The search hits and the steps of their filtering. 
In our analysis, we specifically focused on the products of the food industry, so we did not include research on restaurants, catering establishments, and those on various casseroles, boiled and fried foods served on plates. Moreover, articles on children's dietary habits and on healthy food provision were also not included. The accessed full-length articles were evaluated by two authors (B.P. and Á.T.). Any contested issues were resolved by three authors (B.P., Á.T. and Z.L.).

\section{Results}

The main question of our research is what influences consumers in their perception of the positive effects of a given product on health, which, for the sake of simplification, we will refer to as the healthiness of the product. We provide a comprehensive display of the main results of the articles on the topic in Table 1, then we analyse them, reviewing the points of agreement and opposition.

Table 1. The articles included in the literature analysis and their main Claims.

\begin{tabular}{|c|c|c|c|c|c|}
\hline Source & Year & Country & Method & Item Number & Main Claims \\
\hline $\begin{array}{c}\text { Marques da Rosa, } \\
\text { Spence and Miletto } \\
\text { Tonetto [23] }\end{array}$ & 2019 & Brazil & $\begin{array}{c}2 \times 3 \\
\text { within-groups } \\
\text { experimental } \\
\text { design; } 2 \times 2 \times 2 \\
\text { intra-groups } \\
\text { experiment design }\end{array}$ & $50+102$ & $\begin{array}{l}\text { - A buttered product was } \\
\text { considered healthier in a } \\
\text { round, red and } \\
\text { yellow packaging } \\
\text { - The colour and shape of the } \\
\text { packaging influence } \\
\text { perceived healthiness }\end{array}$ \\
\hline $\begin{array}{l}\text { Pires, de Noronha } \\
\text { and Trindade [24] }\end{array}$ & 2019 & Brazil & $\begin{array}{l}\text { Online survey; } \\
\text { focus groups }\end{array}$ & $263+16$ & $\begin{array}{l}\text { In the case of Bolognese } \\
\text { sauce, consumers prefer less } \\
\text { sodium to omega-3 content }\end{array}$ \\
\hline $\begin{array}{l}\text { Yarar, Machiels } \\
\text { and Orth [25] }\end{array}$ & 2019 & $\begin{array}{c}\text { Not } \\
\text { indicated }\end{array}$ & $\begin{array}{c}\text { One factorial } \\
\text { between subject } \\
\text { design }\end{array}$ & $78+144$ & $\begin{array}{l}\text { - Consumers consider a } \\
\text { product in packaging that } \\
\text { resembles a slim human } \\
\text { figure healthier, especially if } \\
\text { they themselves do not } \\
\text { have such a figure } \\
\text { The shape of the packaging } \\
\text { plays an important role in } \\
\text { the perceived healthiness of } \\
\text { the product }\end{array}$ \\
\hline Machín et al. [26] & 2018 & Uruguay & $\begin{array}{l}\text { shopping situation } \\
\text { (on online surface) }\end{array}$ & 1182 & $\begin{array}{l}\text { "FOP nutrition labelling } \\
\text { schemes effectively } \\
\text { improved the average } \\
\text { healthfulness of food choice } \\
\text { by respondents." (p. 60) } \\
\text { Health motivation can play } \\
\text { a key role in the use of FOP } \\
\text { (front of package) } \\
\text { nutrition information }\end{array}$ \\
\hline
\end{tabular}


Table 1. Cont.

\begin{tabular}{|c|c|c|c|c|c|}
\hline Source & Year & Country & Method & Item Number & Main Claims \\
\hline Hartmann et al. [27] & 2018 & $\begin{array}{c}\text { UK, Sweden, } \\
\text { Poland, } \\
\text { France }\end{array}$ & Online survey & 1950 & $\begin{array}{l}\text { - Indicators of perceived } \\
\text { healthiness: searching for } \\
\text { information, knowledge on } \\
\text { nutrition, and the health } \\
\text { effects of the nutrients. } \\
\text { There was a willingness to } \\
\text { pay extra for "Free-from" } \\
\text { products among those who } \\
\text { look for information and } \\
\text { prefer natural products. }\end{array}$ \\
\hline
\end{tabular}

- The colour, shape, material of and the illustrations on the packaging differ between the products claimed healthy and those considered "normal" in

Festila and Chrysochou [28] 2018

Denmark, United States general and also according to product category

- $\quad$ Products considered healthier appear on the market with lighter, matter or more balanced colours and in angular packaging in the examined countries

- $\quad$ The biggest health advantage for consumers of frankfurters can be achieved through a $\begin{array}{ccc}\text { Polizer Rocha et al. [29] } 2018 \quad \text { Brazil } & \begin{array}{c}\text { test, EsSense } \\ \text { profile, attitudinal }\end{array}\end{array}$ decreased sodium- and fat content. Omega-3 and fibre source are less preferred features in this product

- Food-literacy has a positive effect on the attitudes of the "dietary-gatekeepers" consumer group towards

$\begin{array}{llcc}\text { Wijayaratne et al. [30] } & 2018 & \text { Australia } & \begin{array}{c}\text { Two stage online } \\ \text { survey }\end{array}\end{array}$

Wijayaratne et al. [30] 2018 survey healthy food

- Those with higher food-literacy are more confident in the preparation of a healthier diet

\begin{tabular}{|c|c|c|c|c|c|}
\hline Lee et al. [31] & 2018 & Taiwan & Survey & 122 & $\begin{array}{l}\text { - Although a bio label } \\
\text { influences perceived } \\
\text { healthiness, it does not } \\
\text { increase the consumption of } \\
\text { such products among } \\
\text { "health externals" }\end{array}$ \\
\hline $\begin{array}{l}\text { Vila-López and } \\
\text { Küster-Boluda [32] }\end{array}$ & 2018 & Spain & $\begin{array}{l}\text { Experimental } \\
\text { sessions }\end{array}$ & 300 & $\begin{array}{l}\text { - Younger consumers are } \\
\text { more influenced by } \\
\text { aesthetic/commercial signs } \\
\text { (colours) than by "technical } \\
\text { cues" (healthy messages) }\end{array}$ \\
\hline
\end{tabular}


Table 1. Cont.

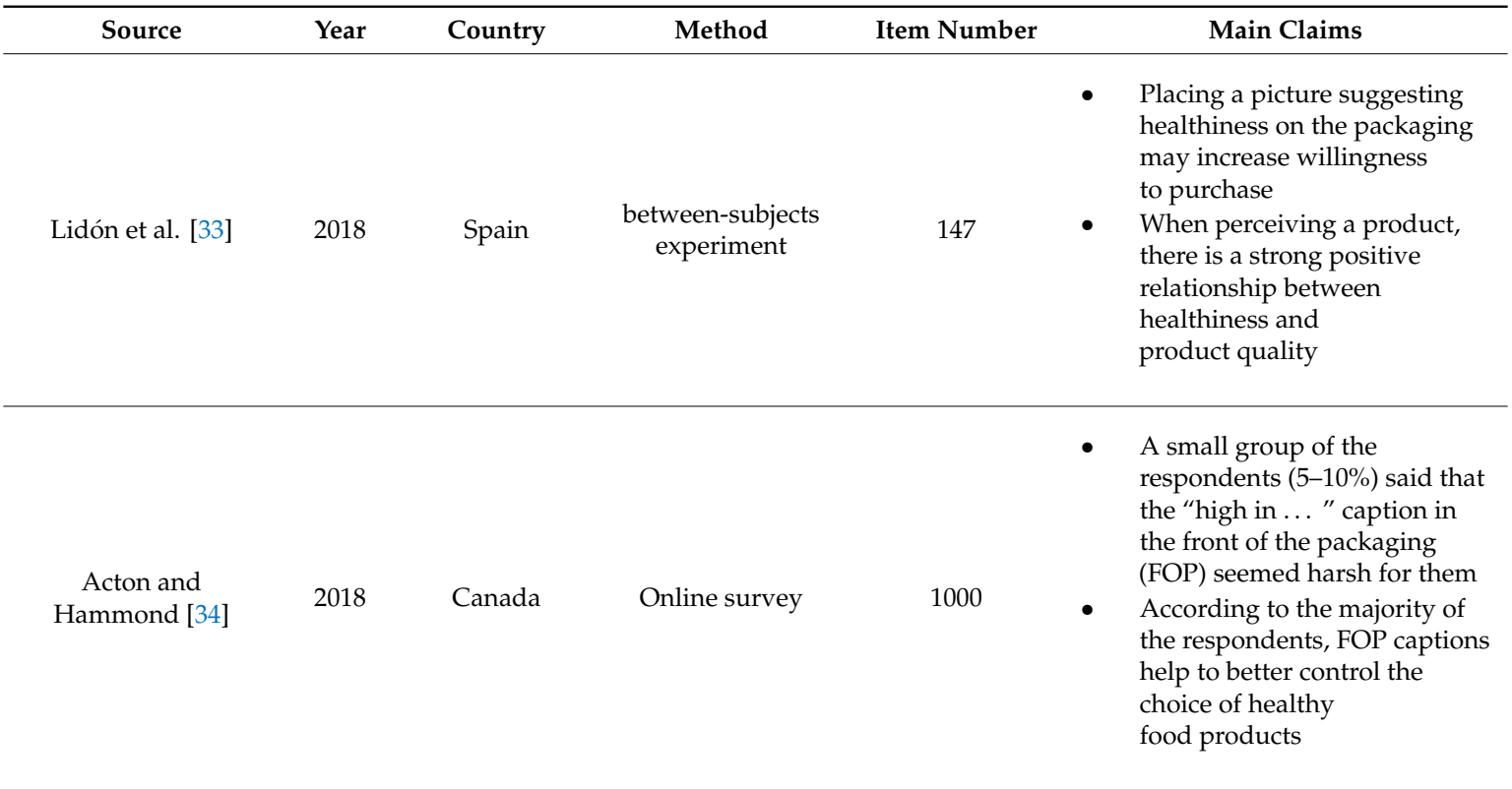

- Communicating the health benefits of the fat composition resulting from the diet of grass-fed beef increased overall liking and purchase intent

Carabante et al. [35] 2018 USA
$\begin{gathered}\text { Consumer test, } \\ \text { questionnaire }\end{gathered}$

- "Health Benefit Information" (HBI) decreased the effect of juiciness and tenderness on overall liking

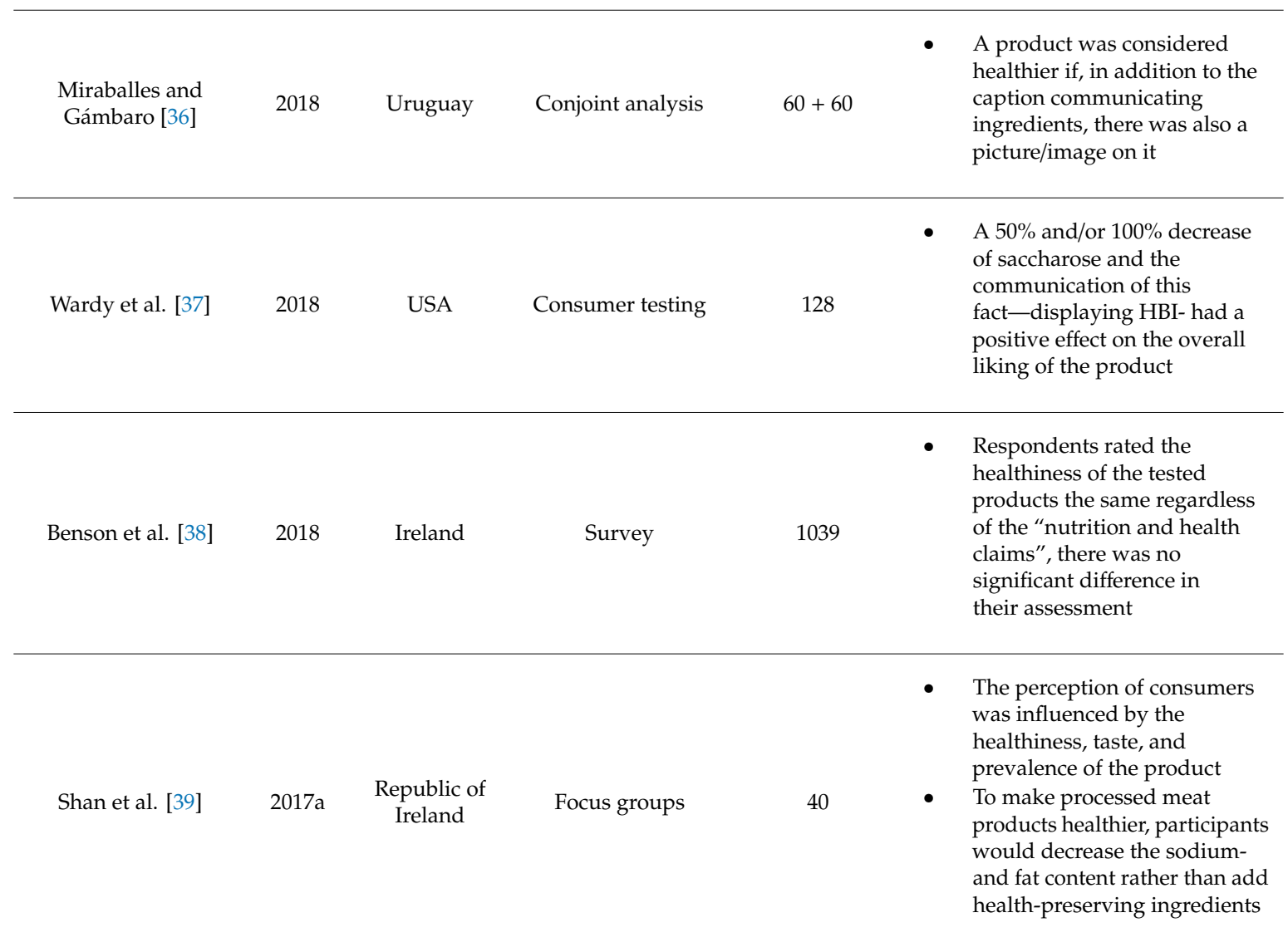


Table 1. Cont.

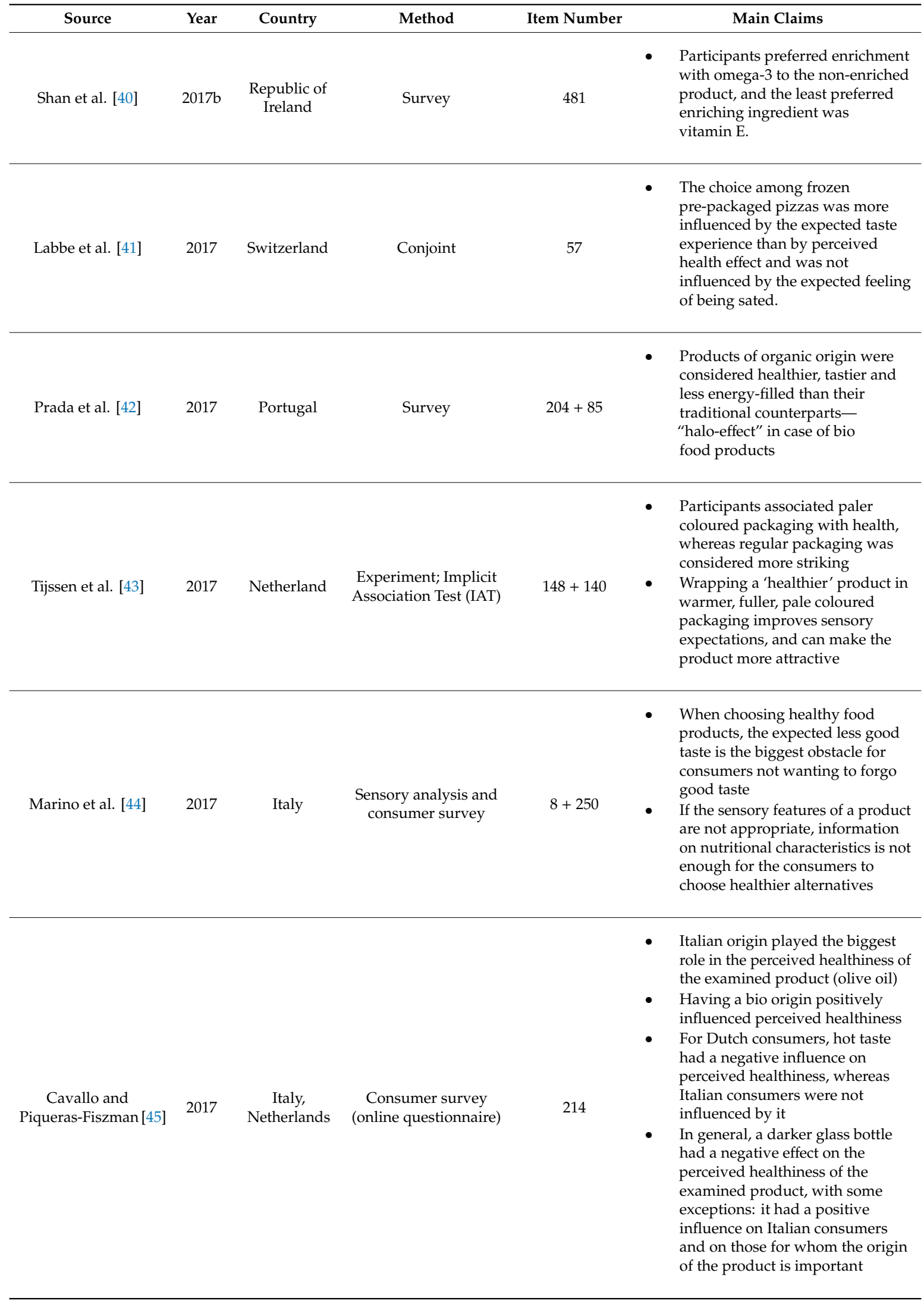


Table 1. Cont.

\begin{tabular}{|c|c|c|c|c|c|}
\hline Source & Year & Country & Method & Item Number & Main Claims \\
\hline $\begin{array}{l}\text { Gineikiene, Kiudyte } \\
\text { and Degutis [46] }\end{array}$ & 2017 & Lithuania & $\begin{array}{l}\text { Survey; Structural } \\
\text { equation modeling }\end{array}$ & 295 & $\begin{array}{l}\text { - Health-conscious consumers tend } \\
\text { to disregard messages related to } \\
\text { the health benefits of functional } \\
\text { foods, and prefer bio } \\
\text { food products } \\
\text { In the case of functional, organic, } \\
\text { and traditional products, } \\
\text { scepticism towards health claims } \\
\text { has a stronger negative effect on } \\
\text { the perceived healthiness than the } \\
\text { effect of health consciousness }\end{array}$ \\
\hline
\end{tabular}

- Information on the ingredients and nutritional values of cashewand soy drinks and functional statements related to this information have a positive effect on consumers' perception of Rebouças et al. [47] $2017 \quad$ Brazil $\quad$ Sensory evaluation $\quad 96 \quad$ healthiness and of nutritional values

- The extent of consumer attention paid to a healthy diet and food neophobia did not influence perceived healthiness of the product.

\begin{tabular}{|c|c|c|c|c|c|}
\hline $\begin{array}{l}\text { Tleis, Callieris and } \\
\text { Roma [48] }\end{array}$ & 2017 & Lebanon & Face-to-face survey & 320 & $\begin{array}{l}\text { - Lebanese consumers purchase bio- } \\
\text { products because they consider } \\
\text { them healthier and safer }\end{array}$ \\
\hline $\begin{array}{l}\text { Brečić, Mesić, and } \\
\text { Cerjak [49] }\end{array}$ & 2017 & Croatia & Face-to-face interviews & 500 & $\begin{array}{l}\text { - The dominant factor explaining } \\
18.8 \% \text { of the sample is "health and } \\
\text { sensory characteristics". The } \\
\text { factor includes the sensory } \\
\text { characteristics (taste, smell) of the } \\
\text { product and its composition } \\
\text { One segment is the "healthy and } \\
\text { tasty food lovers" who are } \\
\text { sensitive to the "inner" } \\
\text { characteristics of the food: they } \\
\text { are concerned about additives and } \\
\text { artificial ingredients and prefer } \\
\text { foods rich in vitamins } \\
\text { and minerals }\end{array}$ \\
\hline Thomson et al. [50] & 2017 & $\begin{array}{l}\text { Melbourne, } \\
\text { Shanghai, } \\
\text { Vietnam, } \\
\text { Indonesia, } \\
\text { Singapore }\end{array}$ & Online survey & 3951 & $\begin{array}{l}\text { - } \quad \text { there are differences in the } \\
\text { perceived healthiness of a certain } \\
\text { product between respondents } \\
\text { from different countries } \\
\text { sweetened, higher circulation } \\
\text { products and children's drinks } \\
\text { were considered healthier in } \\
\text { Vietnam, Shanghai and Indonesia } \\
\text { than in Singapore and Melbourne }\end{array}$ \\
\hline
\end{tabular}


Table 1. Cont.

\begin{tabular}{|c|c|c|c|c|c|}
\hline Source & Year & Country & Method & Item Number & Main Claims \\
\hline $\begin{array}{l}\text { Anders and } \\
\text { Schroeter [52] }\end{array}$ & 2017 & Canada & Survey & 8114 & $\begin{array}{l}\text { Taste, convenience and affordability } \\
\text { are more important than information } \\
\text { related to healthiness and the } \\
\text { resulting benefits }\end{array}$ \\
\hline Talati et al. [53]. & 2016 & Australia & Survey & 2058 & $\begin{array}{l}\text { - Testing different FoP labels and their } \\
\text { effect on perceived healthiness } \\
\text { "daily intake guide" and "multiple } \\
\text { traffic light" had a positive effect on } \\
\text { the global perception of the product } \\
\text { compared to when no FoP labels } \\
\text { were used } \\
\text { - Nevertheless, FoP labels only had a } \\
\text { weaker effect on perceived } \\
\text { healthiness, but a bigger impact on } \\
\text { global evaluations }\end{array}$ \\
\hline
\end{tabular}

- Health-oriented consumers are open to health-enhancing wine products, and their willingness to pay is also higher. Consumers of wine think that $\begin{array}{llll}\text { Samoggia [54] } & 2016 & \text { Italy } & \text { Face-to-face survey }\end{array}$ against hypertension and atherosclerosis.

- Consumers consider wine a healthy product

- American consumers appreciated the functional values provided by bio foods more than German consumers

Seegebarth et al. [55] $2016 \quad \begin{gathered}\text { USA, } \\ \text { Germany }\end{gathered} \quad$ Survey $\quad 206+240$
did. Moreover, American consumers purchase bio food because they consider them healthier and of better quality.

- Respondents expect different health benefits from two products perceived equally healthy ("physical well-being, outward appearance, energy dimensions" vs. "emotional well-being, self-management and social responsibility")

- The weight of the consumer influences their perception of the calorie content of a product considered healthy, while this effect is less pronounced in the case of "unhealthy" food

Larkin and
Martin [57] $2016 \quad$ UK $\quad \begin{gathered}\text { Experimental } \\ \text { sessions }\end{gathered}$

Larkin and sessions

- Consumers underestimate the calorie content of foods considered healthy compared to those considered unhealthy

- $\quad$ Perceived healthiness and perceived calorie content are not influenced by the physical state of the product (e.g., liquid or solid)

- $\quad$ Participants perceived more processed

Szocs and

Lefebvre [58]
2016

USA
Within subjects experiment, lab study, between subject design,
$122+111+166$ products less healthy and richer in calories

- $\quad$ Participants considered the less processed fruit and yoghurt plate healthier than the more processed smoothie 
Table 1. Cont.

\begin{tabular}{|c|c|c|c|c|c|}
\hline Source & Year & Country & Method & Item Number & Main Claims \\
\hline Lazzarini et al. [59] & 2016 & Switzerland & Experiment & 85 & $\begin{array}{l}\text { The perceived healthiness and the } \\
\text { perceived environmentally friendly } \\
\text { nature of a product correlate } \\
\text { The indicators of perceived } \\
\text { healthiness: product category, fat } \\
\text { content, extent of processing and the } \\
\text { indication of organic origin }\end{array}$ \\
\hline
\end{tabular}

- Consumers are willing to pay more for "healthy" products if objective information on the nutritional composition is available

Jo et al. [60] 2016 France $\begin{array}{r}\begin{array}{c}\text { Framed field } \\ \text { experiment }\end{array} \\ \text { and }\end{array}$

- Information on nutritional value increases willingness to pay for "healthy" foods, while decreases it for foods considered unhealthy

\begin{tabular}{|c|c|c|c|c|c|}
\hline $\begin{array}{c}\text { Fenko, Lotterman and } \\
\text { Galetzka [61] }\end{array}$ & 2016 & Netherlands & Questionnaire & 165 & $\begin{array}{l}\text { Products in angular packaging were } \\
\text { perceived healthier than those in } \\
\text { rounded packaging } \\
\text { The higher a consumer's general } \\
\text { health interest, the less they } \\
\text { considered a product healthy } \\
\text { Product category significantly } \\
\text { influenced perceived healthiness, } \\
\text { while brand name did not }\end{array}$ \\
\hline Hipp et al. [62] & 2016 & USA & Survey & 2015 & $\begin{array}{l}\text { - The examined signs and symbols that } \\
\text { were displayed on vending machines } \\
\text { and at cafés in order to foster } \\
\text { health-conscious food choices did not } \\
\text { help consumer decision }\end{array}$ \\
\hline Rizk \& Treat [63] & $2015 a$ & USA & Survey & 272 & $\begin{array}{l}\text { In the case of products in bigger } \\
\text { packaging/portions participants had } \\
\text { difficulty in distinguishing their } \\
\text { perceived healthiness }\end{array}$ \\
\hline Rizk and Treat [64] & $2015 b$ & USA & Survey & 169 & $\begin{array}{l}\text { - Single women mostly relied on fat- } \\
\text { and fibre content when assessing the } \\
\text { healthiness of a product } \\
\text { Displaying protein- and sugar content } \\
\text { mitigated reliance on fat- and } \\
\text { fibre content }\end{array}$ \\
\hline $\begin{array}{l}\text { Sütterlin and } \\
\text { Siegrist [65] }\end{array}$ & 2015 & Switzerland & Experiments & $\begin{aligned} 164+ & 202+251 \\
+ & 162\end{aligned}$ & $\begin{array}{l}\text { - people assess the healthiness of a } \\
\text { product with the help of simple } \\
\text { heuristics-e.g., in the case of fructose: } \\
\text { fruit-healthy-see health halo effect }\end{array}$ \\
\hline Wąsowicz et al. [66] & 2015 & Poland & $\begin{array}{l}\text { Focus group, } \\
\text { survey }\end{array}$ & $8+90$ & $\begin{array}{l}\text { consumers associate certain colours } \\
\text { with the healthiness of the product. } \\
\text { yellow, blue, red and green colours } \\
\text { may indicate healthiness } \\
\text { blue and yellow colours evoked } \\
\text { positive emotions both from the } \\
\text { perspective of healthiness and } \\
\text { of naturalness }\end{array}$ \\
\hline
\end{tabular}


Table 1. Cont.

\begin{tabular}{|c|c|c|c|c|c|}
\hline Source & Year & Country & Method & Item Number & Main Claims \\
\hline Grubor et al. [69] & 2015 & Serbia & $\begin{array}{l}\text { Focus groups, } \\
\text { survey }\end{array}$ & $?+300$ & $\begin{array}{l}\text { - "Consumers' health attitudes" mostly } \\
\text { influence the consumption of enriched } \\
\text { products the pre-enrichment version } \\
\text { of which they had already been } \\
\text { familiar with }\end{array}$ \\
\hline
\end{tabular}

- $\quad$ Regardless of the label, participants considered chocolate tastier, and a muesli bar healthier

- A frowning emoji on a white background had the effect of a muesli bar being considered less tasty and less healthy

Vasiljevic, Pechey, and Marteau [70]
2015

UK experiment
955

- Emojis had a stronger influence on the perception of healthiness and tastiness of snacks than did coloured labels

- Frowning emojis have a stronger influence than smiley ones on perceived healthiness for products where perception of healthiness is influenced by the health halo effect
- $\quad$ The colour red influences the assessment of products considered unhealthy (dangerous) more than that of healthy products

\begin{tabular}{|c|}
\hline $\begin{array}{l}\text { Reutner, Genschow } \\
\text { and Wänke [71] }\end{array}$ \\
\hline
\end{tabular}

- Using red colour mitigated the consumption of foods considered unhealthy, and also influenced the choice of these products

\begin{tabular}{|c|c|c|c|}
\hline $\begin{array}{c}\text { Thomsen and } \\
\text { Hansen [72] }\end{array}$ & 2015 & Denmark & $\begin{array}{l}\text { qualitative pilot } \\
\text { study; survey }\end{array}$ \\
\hline
\end{tabular}

- Improving consumer knowledge on healthy nutrition could help to make healthy food choices

- It is difficult to improve the knowledge of consumers who take less interest in healthy nutrition

- $\quad$ Perceived usefulness of nutritional information is of key importance when making decisions related to healthy nutrition

Dharni and Gupta [73]
- Understanding information increases perceived usefulness, while the increase of perceived usefulness facilitates choosing betterhealthier- food 
Table 1. Cont.

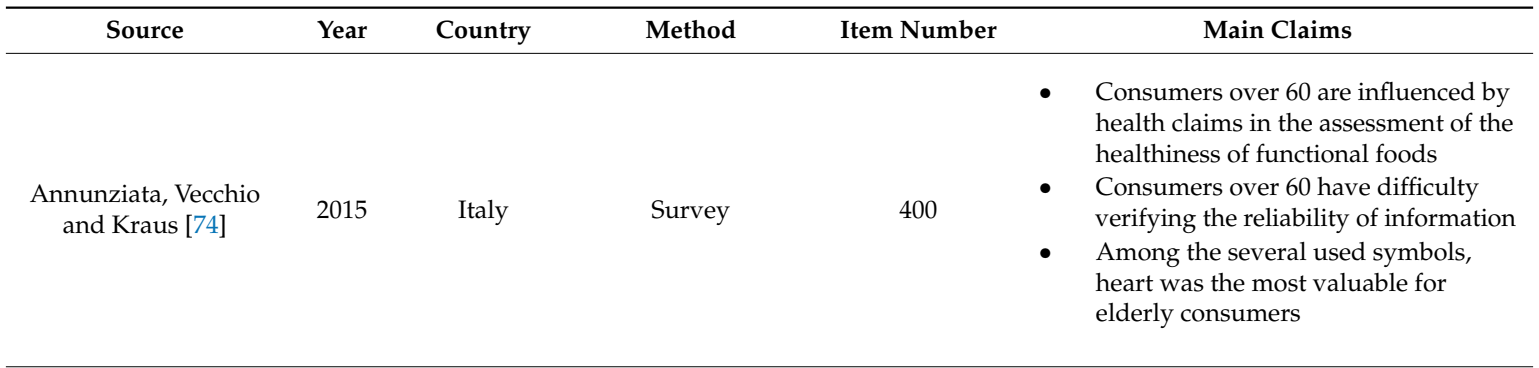

- $\quad$ The issue of healthiness is less important in the case of "utilitarian food products" than for hedonic foods

$\begin{array}{llll}\text { Maehle et al. [75] } 2015 \quad \text { USA } & \text { Conjoint analysis }\end{array}$

- Moreover, in the case of "utilitarian food products", the healthiness of the product is the least important feature compared to the taste and price of the product and the usage of "environmental label"

\begin{tabular}{|c|c|c|c|c|c|}
\hline $\begin{array}{l}\text { Bucher, Müller \& } \\
\text { Siegrist [76] }\end{array}$ & 2015 & Switzerland & Survey & 85 & $\begin{array}{l}\text { - Lay consumers assessed the } \\
\text { healthiness of a product according to } \\
\text { aspects similar to those of experts' } \\
\text { When making decisions, lay } \\
\text { consumers ignored the quantity of } \\
\text { saturated fat, protein, and sodium in } \\
\text { the product } \\
\text { Lay consumers were quite able to } \\
\text { assess the nutrition profile of } \\
\text { individual food items, but were less } \\
\text { able to do so with complete dishes }\end{array}$ \\
\hline Kraus [77] & 2015 & Poland & Survey & 200 & $\begin{array}{l}\text { The most important health-related } \\
\text { features can be ranked the following } \\
\text { way: (1) strengthens the immune } \\
\text { system (2) lowers the risk of } \\
\text { tumour-related diseases (3) lowers the } \\
\text { risk of cardiovascular diseases }\end{array}$ \\
\hline Rodman et al. [78] & 2014 & $\begin{array}{c}\text { USA } \\
\text { (Baltimore, } \\
\text { Maryland) }\end{array}$ & In-depth interview & 36 & $\begin{array}{l}\text { - Organic origin is important for } \\
\text { consumers when assessing the } \\
\text { healthiness of a product. When } \\
\text { communicating the healthiness of the } \\
\text { product, organic origin can have } \\
\text { effectiveness similar to other } \\
\text { health messages. }\end{array}$ \\
\hline Orquin [79] & 2014 & Denmark & $\begin{array}{l}\text { Brunswik lens } \\
\text { model }\end{array}$ & 1329 & $\begin{array}{l}\text { Perceived healthiness mainly depends } \\
\text { on two factors: product category and } \\
\text { consumer knowledge on } \\
\text { individual products } \\
\text { - Consumers underestimate the } \\
\text { healthiness of milk and yoghurt and } \\
\text { overestimate that of butters } \\
\text { and cheeses } \\
\text { Consumers are inclined to perceive a } \\
\text { product healthier if they are familiar } \\
\text { with it }\end{array}$ \\
\hline
\end{tabular}


Table 1. Cont.

\begin{tabular}{|c|c|c|c|c|c|}
\hline Source & Year & Country & Method & Item Number & Main Claims \\
\hline $\begin{array}{l}\text { Carrete and } \\
\text { Arroyo [80] }\end{array}$ & 2014 & Mexico & $\begin{array}{l}\text { In-depth } \\
\text { interviews, } \\
\text { focus groups }\end{array}$ & $8+30$ & $\begin{array}{l}\text { In general, the taste, colour, and } \\
\text { texture of a product are more } \\
\text { important for consumers than } \\
\text { nutritional characteristics, which } \\
\text { hinders healthier nutrition }\end{array}$ \\
\hline $\operatorname{Lin}[81]$ & 2014 & Taiwan & $\begin{array}{c}2 \times 2 \text { experimental } \\
\text { design }\end{array}$ & $170+177$ & $\begin{array}{l}\text { happier people are more variety } \\
\text { seeking in the case of healthful } \\
\text { products or products they are not } \\
\text { familiar with, while sadder people are } \\
\text { more open to variety in the case of } \\
\text { hedonic or familiar products } \\
\text { The type of the product "(hedonic vs. } \\
\text { Healthful products)" influences the } \\
\text { relationship between variety seeking } \\
\text { and the mood of the consumer }\end{array}$ \\
\hline
\end{tabular}

Table 1 clearly shows that numerous factors influence consumers when assessing the healthiness of a product. In our literature analysis, we categorized these factors as follows:

- Communicated information [26,27,34,35,37,47,60,62,65,73,74,77];

- $\quad$ The shape and colour of the product packaging $[23,25,28,32,33,43,61,66,70,71]$;

- $\quad$ The ingredients of the product $[24,29,39,40,49,57,64,76] ;$

- $\quad$ Product category $[54,61,69,70,75,78]$;

- $\quad$ Organic origin of the product $[5,31,42,45,46,48,51,55,68]$;

- $\quad$ The taste and other sensory features of the product $[41,44,52,70,79]$.

The perceived healthiness of a food product is influenced by numerous factors. For bigger clarity, the main points of the research results are summarized in Figure 2.

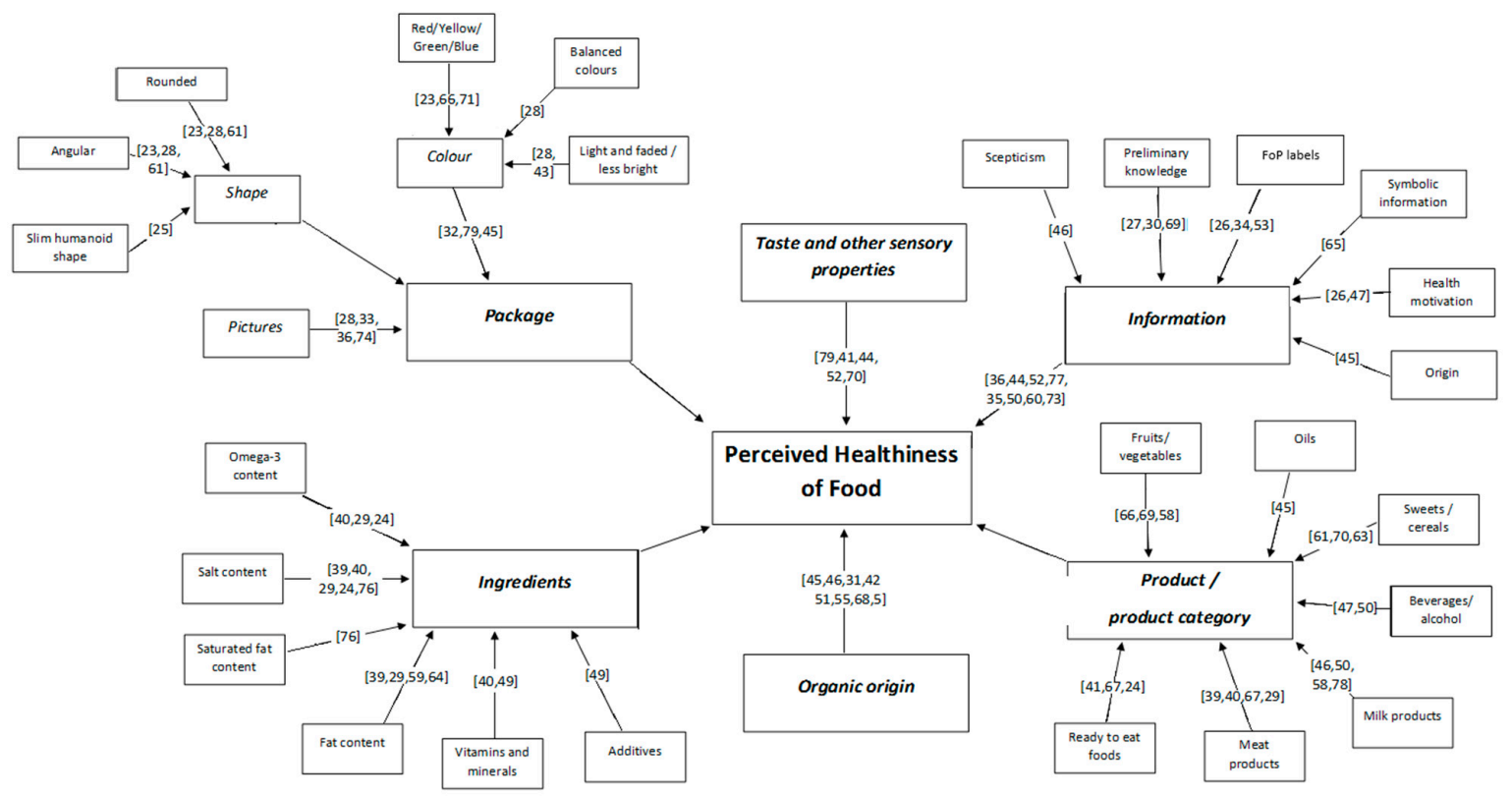

Figure 2. Factors influencing perceived healthiness.

\subsection{The Effect of the Communicated Information on the Perceived Healthiness of a Product}

When companies provide consumers with information related to nutritional value or to health effects in some way on the product packaging, it has a positive effect on perceived 
healthiness $[26,34-36,47]$. At the same time, care must be taken that consumers comprehend this information correctly, so that they do not evoke undesired associations [62], and consumer scepticism related to health claims must also be taken into account [74], as in this case information may even have a negative effect on assessing healthiness.

All this also entails how much of the messages communicated through the product a consumer will comprehend and thus how healthy they will perceive the product. This is supported by the previous knowledge of the consumer, which influences perceived healthiness to a great extent $[27,69,78]$. Moreover, perceived healthiness of a product is further improved by adding a picture of the product to the communicated information [36] and is also affected by FoP labels and health claims $[26,34,38,53]$. Although several studies show that FoP labels help consumers choose healthier foods [26,34], due to the diversity of FoP labels, it cannot be clearly stated that their use always helps greatly in increasing the perceived healthiness of the product [53].

The health motivation of the consumer also influences the assessment of the product; Machín et al. [26] maintain that it plays a pivotal role in the way front of package information is used. In contrast, according to the results of Rebouças et al. [47], consumer interest in healthy nutrition does not influence the acceptance and perceived healthiness and nutritional value of the product they examined ("cashew nut beverage").

\subsection{The Influence of the Shape and Colour of the Product Packaging}

Research results confirm that the shape and colour of the product packaging influence the perceived healthiness of the product, but from certain aspects the results contradict each other. Whereas Marques et al. [23] maintain that a product is perceived to be healthier in a rounded packaging, other researchers $[28,61]$ claim that consumers perceive a product healthier in angular shaped packaging. A further result related to the shape of the packaging is that packaging resembling a slim human figure is perceived healthier [25].

The influence of the colour of the packaging has also been examined by several researchers. According to the results of Marques et al.'s research [23], buttered products were perceived healthier in a red and yellow coloured packaging. The effect of the colour red is mentioned by several other studies. Wasowicz et al. [66], along with yellow, green and blue, mention the colour red as a colour referring to health. At the same time, Reutner et al. [71] assert that the colour red can have a significant effect on the refusal of unhealthy foods. Certain colours and hues, however, can imply that the product is less healthy: research participants considered dark glass [45] and colours hinting at artificiality ("heather", "pink", "celadon") [66] to be referring to unhealthy or less healthy products.

Contrasts resulting from the perception of colour can be attributed to the variety of products and their different packaging investigated in the studies; so it is possible that in the case of a buttered product, the red \& yellow colour combination found by Marques et al. [23] was perceived healthier, while it can be different for other products. Therefore, when discussing the effect of colour, it is important to acknowledge the influence of product category. Differences between countries are also important; so for example, in Denmark, paler, whereas in the United States, balanced colour tones are more standard on healthy products [28]. Moreover, the effect of colour can differ according to the age of the consumer: for example, with young people, colours have a stronger effect than health messages [32].

\subsection{The Effect of the Ingredients of a Product on its Perceived Healthiness}

Results related to ingredients show that consumers mostly pay attention to the ingredients that nutrition experts emphasize in relation to healthy nutrition. The majority of the research studies we have examined address sodium- and fat content as well as omega- 3 content. According to the results of Lazzarini et al.'s [59] research, the fat content of a product is an indicator of perceived healthiness for consumers. 
Whether it is Bolognese sauce, frankfurter sausages, or other processed meat products, consumers prefer a reduced sodium- and fat content, so that is how a company can make consumers perceive these products healthier $[24,29,39]$. Moreover, while there are consumers who rely on the fatand fibre content of the product for its perceived healthiness [64], others ignore the protein-, sodium-, and saturated fat content when making decisions [76].

The other ingredient featuring in numerous studies was omega-3. In several cases, consumers would choose to change an ingredient other than the fatty acid [24], or they did not consider the product suitable for the addition of omega-3 [29]; at the same time, they prefer if omega-3 fatty acid is added to the product rather than if nothing is added [40].

\subsection{The Effect of Product Category on Perceived Healthiness}

Perceived healthiness is also influenced by the product or product category [75,78]; in fact, in Orquin's [78] research, product category emerged as one of the two main factors based on which consumers perceived the healthiness of a product. In the studies, products assigned to different categories according to different criteria were compared. Fenko et al. [61] compared consumer perception of cereal- and buttered cookies, of which consumers perceived cereal cookies healthier. Vasiljevic et al. [70] compared muesli bars and chocolate, and their results show that, regardless of label, consumers perceived chocolate tastier and muesli bars healthier. According to Maehle et al.'s [75] surprising result, consumers are less concerned about the healthiness of the product if they consume it for the nutritional value (utilitarian products), than in the case of products consumed for pleasure (hedonic products).

\subsection{The Effect of Organic Origin on Perceived Healthiness}

Results of numerous studies have confirmed a positive effect of organic origin on the perceived healthiness of a product $[42,45,48,51,68]$. In addition, organic origin also facilitates the understanding of the communication of "healthy food" [5]. Health-conscious consumers also tend to show openness towards bio foods and generally ignore the health-related messages of functional foods [46].

\subsection{The Effect of the Sensory Features of the Product on Perceived Healthiness}

The sensory features of the product also play a role in its perceived healthiness. The taste and other sensory features of the product may dominate over the perception of healthiness $[41,52,79]$, and if the sensory features of the product do not satisfy the consumer, then communicating the nutritional value is not enough to make the product accepted [44].

\section{Discussion}

The aim of our literature analysis was to explore the factors that influence the perceived healthiness of food products. Numerous studies set out to discover what influences the perceived healthiness of individual products in the time period we focused on. In the present article, we only considered research results related to foods.

Based on the research results, we identified six categories that influence perceived healthiness of a product: the effect of the communicated information, product category, the shape and colour of the product packaging, the ingredients of the product, the organic origin of the product and the taste and other sensory features of the product.

The effect of the communicated information clearly influences perceived healthiness; at the same time, previous knowledge clearly affects how this information influences perception. Product category is a main factor in the perceived healthiness of a product. In recent years, a diverse range of product categories has been tested, which makes generalizations difficult.

The most numerous contradictory research results were related to the shape and colour of the product packaging, which calls for further investigation. Research results are ambiguous concerning whether angular or rounded packaging is more suitable to communicate healthiness. One of the most 
researched colours is the colour red. Nevertheless, results related to the colour red do not point in the same direction.

Research results related to the ingredients of the product confirm that reducing the sodium-, sugarand fat content increases consumer acceptance of the improved product in terms of health; at the same time, research does not give a definite answer regarding consumer perception of the possible enriching ingredients.

The organic origin of the product positively influences perceived healthiness. Health halo effect emerged in several studies in connection with bio products.

Basically, the taste and other sensory features of the product dominate over perception of healthiness. A common result of the examined studies showed that the unsuitability of sensory features cannot be balanced out by favourable perceived healthiness.

Our collected results and their juxtaposition can help with the proper planning of product development and marketing communication, and they also raise further research questions related to the inconsistent results. Our conclusions can serve as a baseline from several aspects when devising packaging of a new product. They can help with the proper design of the packaging, both in terms of shape and the used colours, and with choosing the right FoP labels. The choice of the labels used on the packaging requires special care. The type of health claim communicated by the company has to be considered carefully, provided that the use of a health claim is effective in the first place. At the same time, it is also important to consider that communicating the different ingredients may be an effective method to reach its goal.

Within the categories, we have found several conflicting results, as well as unanswered research questions, which call for further research. The most important aim of further research may be to gauge the effect of the discovered aspects relative to each other, even comparing all the aspects.

Further research may also aim at clarifying the emerged controversial results, as the research results are not uniform for example in connection with the shape of packaging and colours that evoke a healthy feeling, keeping in mind that these factors may change according to product category. Apart from clarifying discrepancies, further research may take on the task of testing specific features on different food products. Treating the constructed system as a complex entity, it is worth examining whether a different colour and shape of packaging is justified to communicate the health benefits of each food.

\section{Limitations}

In the course of our literature analysis, we encountered several barriers that have to be taken into account when evaluating the results. There has not been a review article on the topic since 2016, even though several new studies have been published since then. As we reviewed only the 2014-2019 time period, we can only report the results of the most modern research. The surfaces used for data collection are also important to mention: during the research, we had no access to the surfaces covering the whole literature, therefore we chose the above described search surfaces, where we could access the full-length articles. Our options were limited by the year-to-year changes in the agreement between the Hungarian Electronic Information Service National Programme (EISZ) and Elsevier [81].

Author Contributions: Conceptualization, B.P. and Á.T.; methodology, B.P.; writing-original draft preparation, B.P.; writing—review and editing, Á.T.; visualization, B.P.; supervision, Z.L. All authors have read and agreed to the published version of the manuscript.

Funding: The Project is supported by the European Union and co-financed by the European Social Fund (grant agreement no. EFOP-3.6.3-VEKOP-16-2017-00005).

Conflicts of Interest: The authors declare no conflict of interest. 


\section{References}

1. Hawkes, C. Defining "healthy" and "unhealthy" foods. An international review. Prepared for the Office of Nutrition Policy and Promotion. Health Can. 2009. Available online: https://www.canada.ca/en/healthcanada/services/food-nutrition/healthy-eating/nutrition-policy-reports/defining-healthy-unhealthy-foodsinternational-review-2009-executive-summary.html (accessed on 23 June 2020).

2. Lobstein, T.; Davies, S. Defining and labelling 'healthy'and 'unhealthy'food. Public Health Nutr. 2009, 12, 331-340. [CrossRef]

3. Campbell, N.; Duhaney, T.; Ashley, L.; Arango, M.; Berg, A.; Flowitt, F.; Gelfer, M.; Kaczorowski, J.; Mang, E.; Morris, D.; et al. A National Model for Defining Healthy and Unhealthy Foods and Beverages-Canadian Health and Scientific Organization. Consensus Statement. 2016. Available online: www.hypertensiontalk. com/position-statements/ (accessed on 23 June 2020).

4. Dickson-Spillmann, M.; Siegrist, M. Consumers' knowledge of healthy diets and its correlation with dietary behaviour. J. Hum. Nutr. Diet. 2011, 24, 54-60. [CrossRef] [PubMed]

5. Rodman, S.O.; Palmer, A.M.; Zachary, D.A.; Hopkins, L.C.; Surkan, P.J. “They Just Say Organic Food Is Healthier": Perceptions of Healthy Food among Supermarket Shoppers in Southwest Baltimore. Cult. Agric. Food Environ. 2014, 36, 83-92. [CrossRef]

6. Gogus, U. A Fundamental Guide for a Healthy Lifestyle and Nutrition; AuthorHouse: Bloomington, IN, USA, 2011.

7. Zaheer, I.S.; Bach, C. Consumers Demand Response Patterns. University of Bridgeport. Available online: https://www.researchgate.net/publication/261993663_consumers_Demand_article_journal_Bach_Finalx (accessed on 1 March 2019).

8. University of Washington Center for Public Health Nutrition (CPHN) Defining "Healthy Foods". Available online: https://nutr.uw.edu/resource/opportunities-for-increasing-access-to-healthy-foods-washington/ (accessed on 26 June 2013).

9. Mai, R.; Hoffmann, S. How to combat the unhealthy= tasty intuition: The influencing role of health consciousness. J. Public Policy Mark. 2015, 34, 63-83. [CrossRef]

10. Howlett, E.A.; Burton, S.; Bates, K.; Huggins, K. Coming to a restaurant near you? Potential consumer responses to nutrition information disclosure on menus. J. Consum. Res. 2009, 36, 494-503. [CrossRef]

11. Steinhauser, J.; Janssen, M.; Hamm, U. Who Buys Products with Nutrition and Health Claims? A Purchase Simulation with Eye Tracking on the Influence of Consumers' Nutrition Knowledge and Health Motivation. Nutrients 2019, 11, 2199. [CrossRef]

12. Plasek, B.; Temesi, Á. The credibility of the effects of functional food products and consumers' willingness to purchase/willingness to pay-review. Appetite 2019, 143, 104398. [CrossRef]

13. Niebylski, M.L.; Redburn, K.A.; Duhaney, T.; Campbell, N.R. Healthy food subsidies and unhealthy food taxation: A systematic review of the evidence. Nutrition 2015, 31, 787-795. [CrossRef] [PubMed]

14. Provencher, V.; Jacob, R. Impact of perceived healthiness of food on food choices and intake. Curr. Obes. Rep. 2016, 5, 65-71. [CrossRef]

15. Alba, J.W.; Williams, E.F. Pleasure principles: A review of research on hedonic consumption. J. Consum. Psychol. 2013, 23, 2-18. [CrossRef]

16. Krishna, A. An integrative review of sensory marketing: Engaging the senses to affect perception, judgment and behavior. J. Consum. Psychol. 2012, 22, 332-351. [CrossRef]

17. Raghunathan, R.; Naylor, R.W.; Hoyer, W.D. The unhealthy= tasty intuition and its effects on taste inferences, enjoyment, and choice of food products. J. Mark. 2006, 70, 170-184. [CrossRef]

18. Jo, J.; Lusk, J.L. If it's healthy, it's tasty and expensive: Effects of nutritional labels on price and taste expectations. Food Qual. Prefer. 2018, 68, 332-341. [CrossRef]

19. Lusk, J.L. Consumer beliefs about healthy foods and diets. PLoS ONE 2019, 14, e0223098. [CrossRef] [PubMed]

20. Petrescu, D.C.; Vermeir, I.; Petrescu-Mag, R.M. Consumer Understanding of Food Quality, Healthiness, and Environmental Impact: A Cross-National Perspective. Int. J. Environ. Res. Public Health 2020, 17, 169. [CrossRef]

21. Riebl, S.K.; Estabrooks, P.A.; Dunsmore, J.C.; Savla, J.; Frisard, M.I.; Dietrich, A.M.; Peng, Y.; Zhang, X.; Davy, B.M. A systematic literature review and meta-analysis: The Theory of Planned Behavior's application to understand and predict nutrition-related behaviors in youth. Eat. Behav. 2015, 18, 160-178. [CrossRef] 
22. Dorota Rudawska, E. Customer loyalty towards traditional products-Polish market experience. Br. Food J. 2014, 116, 1710-1725. [CrossRef]

23. Marques da Rosa, V.; Spence, C.; Miletto Tonetto, L. Influences of visual attributes of food packaging on consumer preference and associations with taste and healthiness. Int. J. Consum. Stud. 2019, 43, 210-217. [CrossRef]

24. Pires, M.A.; de Noronha, R.L.F.; Trindade, M.A. Understanding consumer's perception and acceptance of bologna sausages with reduced sodium content and/or omega-3 addition through conjoint analysis and focus group. J. Sens. Stud. 2019, e12495. [CrossRef]

25. Yarar, N.; Machiels, C.J.; Orth, U.R. Shaping up: How package shape and consumer body conspire to affect food healthiness evaluation. Food Qual. Prefer. 2019. [CrossRef]

26. Machín, L.; Aschemann-Witzel, J.; Curutchet, M.R.; Giménez, A.; Ares, G. Does front-of-pack nutrition information improve consumer ability to make healthful choices? Performance of warnings and the traffic light system in a simulated shopping experiment. Appetite 2018, 121, 55-62. [CrossRef] [PubMed]

27. Hartmann, C.; Hieke, S.; Taper, C.; Siegrist, M. European consumer healthiness evaluation of 'Free-from'labelled food products. Food Qual. Prefer. 2018, 68, 377-388. [CrossRef]

28. Festila, A.; Chrysochou, P. Implicit communication of food product healthfulness through package design: A content analysis. J. Consum. Behav. 2018, 17, 461-476. [CrossRef]

29. Polizer Rocha, Y.J.; Lapa-Guimarães, J.; de Noronha, R.L.F.; Trindade, M.A. Evaluation of consumers' perception regarding frankfurter sausages with different healthiness attributes. J. Sens. Stud. 2018, 33, e12468. [CrossRef]

30. Wijayaratne, S.P.; Reid, M.; Westberg, K.; Worsley, A.; Mavondo, F. Food literacy, healthy eating barriers and household diet. Eur. J. Mark. 2018, 52, 2449-2477. [CrossRef]

31. Lee, H.C.; Chang, C.T.; Cheng, Z.H.; Chen, Y.T. Will an organic label always increase food consumption? It depends on food type and consumer differences in health locus of control. Food Qual. Prefer. 2018, 63, 88-96. [CrossRef]

32. Vila-López, N.; Küster-Boluda, I. Commercial versus technical cues to position a new product: Do hedonic and functional/healthy packages differ? Soc. Sci. Med. 2018, 198, 85-94. [CrossRef]

33. Lidón, I.; Rebollar, R.; Gil-Pérez, I.; Martín, J.; Vicente-Villardón, J.L. The influence the image of the product shown on food packaging labels has on product perception during tasting: Effects and gender differences. Packag. Technol. Sci. 2018, 31, 689-697. [CrossRef]

34. Acton, R.B.; Hammond, D. Do Consumers Think Front-of-Package "High in" Warnings are Harsh or Reduce their Control? A Test of Food Industry Concerns. Obesity 2018, 26, 1687-1691. [CrossRef]

35. Carabante, K.M.; Ardoin, R.; Scaglia, G.; Malekian, F.; Khachaturyan, M.; Janes, M.E.; Prinyawiwatkul, W. Consumer Acceptance, Emotional Response, and Purchase Intent of Rib-Eye Steaks from Grass-Fed Steers, and Effects of Health Benefit Information on Consumer Perception. J. Food Sci. 2018, 83, 2560-2570. [CrossRef] [PubMed]

36. Miraballes, M.; Gámbaro, A. Influence of Images on the Evaluation of Jams using Conjoint Analysis Combined with Check-All-That-Apply (CATA) Questions. J. Food Sci. 2018, 83, 167-174. [CrossRef]

37. Wardy, W.; Jack, A.R.; Chonpracha, P.; Alonso, J.R.; King, J.M.; Prinyawiwatkul, W. Gluten-free muffins: Effects of sugar reduction and health benefit information on consumer liking, emotion, and purchase intent. Int. J. Food Sci. Technol. 2018, 53, 262-269. [CrossRef]

38. Benson, T.; Lavelle, F.; Bucher, T.; McCloat, A.; Mooney, E.; Egan, B.; Collins, C.E.; Dean, M. The impact of nutrition and health claims on consumer perceptions and portion size selection: Results from a nationally representative survey. Nutrients 2018, 10, 656. [CrossRef]

39. Shan, L.C.; Regan, Á.; Monahan, F.J.; Li, C.; Lalor, F.; Murrin, C.; Wall, P.G.; McConnon, Á. Consumer preferences towards healthier reformulation of a range of processed meat products: A qualitative exploratory study. Br. Food J. 2017, 119, 2013-2026. [CrossRef]

40. Shan, L.C.; De Brún, A.; Henchion, M.; Li, C.; Murrin, C.; Wall, P.G.; Monahan, F.J. Consumer evaluations of processed meat products reformulated to be healthier-A conjoint analysis study. Meat Sci. 2017, 131, 82-89. [CrossRef] [PubMed]

41. Labbe, D.; Rytz, A.; Godinot, N.; Ferrage, A.; Martin, N. Is portion size selection associated with expected satiation, perceived healthfulness or expected tastiness? A case study on pizza using a photograph-based computer task. Appetite 2017, 108, 311-316. [CrossRef] 
42. Prada, M.; Garrido, M.V.; Rodrigues, D. Lost in processing? Perceived healthfulness, taste and caloric content of whole and processed organic food. Appetite 2017, 114, 175-186. [CrossRef]

43. Tijssen, I.; Zandstra, E.H.; de Graaf, C.; Jager, G. Why a 'light'product package should not be light blue: Effects of package colour on perceived healthiness and attractiveness of sugar-and fat-reduced products. Food Qual. Prefer. 2017, 59, 46-58. [CrossRef]

44. Marino, R.; Della Malva, A.; Seccia, A.; Caroprese, M.; Sevi, A.; Albenzio, M. Consumers' expectations and acceptability for low saturated fat 'salami': Healthiness or taste? J. Sci. Food Agric. 2017, 97, 3515-3521. [CrossRef]

45. Cavallo, C.; Piqueras-Fiszman, B. Visual elements of packaging shaping healthiness evaluations of consumers: The case of olive oil. J. Sens. Stud. 2017, 32, e12246. [CrossRef]

46. Gineikiene, J.; Kiudyte, J.; Degutis, M. Functional, organic or conventional? Food choices of health conscious and skeptical consumers. Balt. J. Manag. 2017, 12, 139-152. [CrossRef]

47. Rebouças, M.C.; Rodrigues, M.D.C.P.; Freitas, S.M.D.; Ferreira, B.B.A.; Costa, V.D.S. Effect of nutritional information and health claims related to cashew nut and soya milk beverages on consumers' acceptance and perception. Nutr. Food Sci. 2017, 47, 721-730. [CrossRef]

48. Tleis, M.; Callieris, R.; Roma, R. Segmenting the organic food market in Lebanon: An application of k-means cluster analysis. Br. Food J. 2017, 119, 1423-1441. [CrossRef]

49. Brečić, R.; Mesić, Ž.; Cerjak, M. Importance of intrinsic and extrinsic quality food characteristics by different consumer segments. Br. Food J. 2017, 119, 845-862. [CrossRef]

50. Thomson, N.; Worsley, A.; Wang, W.; Sarmugam, R.; Pham, Q.; Februhartanty, J. Country context, personal values and nutrition trust: Associations with perceptions of beverage healthiness in five countries in the Asia Pacific region. Food Qual. Prefer. 2017, 60, 123-131. [CrossRef]

51. Apaolaza, V.; Hartmann, P.; Echebarria, C.; Barrutia, J.M. Organic label's halo effect on sensory and hedonic experience of wine: A pilot study. J. Sens. Stud. 2017, 32, e12243. [CrossRef]

52. Anders, S.; Schroeter, C. Estimating the effects of nutrition label use on Canadian consumer diet-health concerns using propensity score matching. Int. J. Consum. Stud. 2017, 41, 534-544. [CrossRef]

53. Talati, Z.; Pettigrew, S.; Dixon, H.; Neal, B.; Ball, K.; Hughes, C. Do health claims and front-of-pack labels lead to a positivity bias in unhealthy foods? Nutrients 2016, 8, 787. [CrossRef]

54. Samoggia, A. Wine and health: Faraway concepts? Br. Food J. 2016, 118, 946-960. [CrossRef]

55. Seegebarth, B.; Behrens, S.H.; Klarmann, C.; Hennigs, N.; Scribner, L.L. Customer value perception of organic food: Cultural differences and cross-national segments. Br. Food J. 2016, 118, 396-411. [CrossRef]

56. Puska, P.; Luomala, H.T. Capturing qualitatively different healthfulness images of food products. Mark. Intell. Plan. 2016, 34, 605-622. [CrossRef]

57. Larkin, D.; Martin, C.R. Caloric estimation of healthy and unhealthy foods in normal-weight, overweight and obese participants. Eat. Behav. 2016, 23, 91-96. [CrossRef] [PubMed]

58. Szocs, C.; Lefebvre, S. The blender effect: Physical state of food influences healthiness perceptions and consumption decisions. Food Qual. Prefer. 2016, 54, 152-159. [CrossRef]

59. Lazzarini, G.A.; Zimmermann, J.; Visschers, V.H.; Siegrist, M. Does environmental friendliness equal healthiness? Swiss consumers' perception of protein products. Appetite 2016, 105, 663-673. [CrossRef]

60. Jo, J.; Lusk, J.L.; Muller, L.; Ruffieux, B. Value of parsimonious nutritional information in a framed field experiment. Food Policy 2016, 63, 124-133. [CrossRef]

61. Fenko, A.; Lotterman, H.; Galetzka, M. What's in a name? The effects of sound symbolism and package shape on consumer responses to food products. Food Qual. Prefer. 2016, 51, 100-108. [CrossRef]

62. Hipp, J.A.; Becker, H.V.; Marx, C.M.; Tabak, R.G.; Brownson, R.C.; Yang, L. Worksite nutrition supports and sugar-sweetened beverage consumption. Obes. Sci. Pract. 2016, 2, 144-153. [CrossRef]

63. Rizk, M.T.; Treat, T.A. Sensitivity to portion size of unhealthy foods. Food Qual. Prefer. 2015, 45, $121-131$. [CrossRef]

64. Rizk, M.T.; Treat, T.A. Perceptions of food healthiness among free-living women. Appetite 2015, 95, 390-398. [CrossRef]

65. Sütterlin, B.; Siegrist, M. Simply adding the word "fruit" makes sugar healthier: The misleading effect of symbolic information on the perceived healthiness of food. Appetite 2015, 95, 252-261. [CrossRef] [PubMed] 
66. Wąsowicz, G.; Styśko-Kunkowska, M.; Grunert, K.G. The meaning of colours in nutrition labelling in the context of expert and consumer criteria of evaluating food product healthfulness. J. Health Psychol. 2015, 20, 907-920. [CrossRef] [PubMed]

67. Luomala, H.; Jokitalo, M.; Karhu, H.; Hietaranta-Luoma, H.L.; Hopia, A.; Hietamäki, S. Perceived health and taste ambivalence in food consumption. J. Consum. Mark. 2015, 32, 290-301. [CrossRef]

68. Xie, B.; Wang, L.; Yang, H.; Wang, Y.; Zhang, M. Consumer perceptions and attitudes of organic food products in Eastern China. Br. Food J. 2015, 117, 1105-1121. [CrossRef]

69. Grubor, A.; Djokic, N.; Djokic, I.; Kovac-Znidersic, R. Application of health and taste attitude scales in Serbia. Br. Food J. 2015, 117, 840-860. [CrossRef]

70. Vasiljevic, M.; Pechey, R.; Marteau, T.M. Making food labels social: The impact of colour of nutritional labels and injunctive norms on perceptions and choice of snack foods. Appetite 2015, 91, 56-63. [CrossRef]

71. Reutner, L.; Genschow, O.; Wänke, M. The adaptive eater: Perceived healthiness moderates the effect of the color red on consumption. Food Qual. Prefer. 2015, 44, 172-178. [CrossRef]

72. Thomsen, T.U.; Hansen, T. Perceptions that matter: Perceptual antecedents and moderators of healthy food consumption. Int. J. Consum. Stud. 2015, 39, 109-116. [CrossRef]

73. Dharni, K.; Gupta, K. Exploring antecedents of healthy food choices: An Indian experience. Int. J. Consum. Stud. 2015, 39, 101-108. [CrossRef]

74. Annunziata, A.; Vecchio, R.; Kraus, A. Awareness and preference for functional foods: The perspective of older Italian consumers. Int. J. Consum. Stud. 2015, 39, 352-361. [CrossRef]

75. Maehle, N.; Iversen, N.; Hem, L.; Otnes, C. Exploring consumer preferences for hedonic and utilitarian food attributes. Br. Food J. 2015, 117, 3039-3063. [CrossRef]

76. Bucher, T.; Müller, B.; Siegrist, M. What is healthy food? Objective nutrient profile scores and subjective lay evaluations in comparison. Appetite 2015, 95, 408-414. [CrossRef]

77. Kraus, A. Development of functional food with the participation of the consumer. Motivators for consumption of functional products. Int. J. Consum. Stud. 2015, 39, 2-11. [CrossRef]

78. Orquin, J.L. A Brunswik lens model of consumer health judgments of packaged foods. J. Consum. Behav. 2014, 13, 270-281. [CrossRef]

79. Carrete, L.; Arroyo, P. Social marketing to improve healthy dietary decisions: Insights from a qualitative study in Mexico. Qual. Mark. Res. Int. J. 2014, 17, 239-263. [CrossRef]

80. Lin, H.C. The effects of food product types and affective states on consumers' decision making. Br. Food J. 2014, 116, 1550-1560. [CrossRef]

81. Available online: http://eisz.mtak.hu/index.php/en/open-access-english/338-access-to-sciencedirect-scopusand-scival-open-for-the-hungarian-research-community-as-eisz-and-elsevier-work-towards-an-openaccess-pilot-agreement.html (accessed on 15 June 2020). 